\title{
Warm Middle Jurassic-Early Cretaceous high-latitude sea-surface temperatures from the Southern Ocean
}

\author{
H. C. Jenkyns ${ }^{1}$, L. Schouten-Huibers ${ }^{2}$, S. Schouten ${ }^{2}$, and J. S. Sinninghe Damsté ${ }^{2}$ \\ ${ }^{1}$ Department of Earth Sciences, University of Oxford, South Parks Road, Oxford OX1 3AN, UK \\ ${ }^{2}$ NIOZ Royal Netherlands Institute for Sea Research, Department of Marine Organic Biogeochemistry, P.O. Box 59, \\ 1790 Den Burg, Texel, The Netherlands
}

Correspondence to: H. C. Jenkyns (hughj@earth.ox.ac.uk)

Received: 17 March 2011 - Published in Clim. Past Discuss.: 20 April 2011

Revised: 6 December 2011 - Accepted: 14 December 2011 - Published: 2 February 2012

\begin{abstract}
Although a division of the Phanerozoic climatic modes of the Earth into "greenhouse" and "icehouse" phases is widely accepted, whether or not polar ice developed during the relatively warm Jurassic and Cretaceous Periods is still under debate. In particular, there is a range of isotopic and biotic evidence that favours the concept of discrete "cold snaps", marked particularly by migration of certain biota towards lower latitudes. Extension of the use of the palaeotemperature proxy TEX 86 back to the Middle Jurassic indicates that relatively warm sea-surface conditions (26$\left.30^{\circ} \mathrm{C}\right)$ existed from this interval $(\sim 160 \mathrm{Ma})$ to the Early Cretaceous $(\sim 115 \mathrm{Ma})$ in the Southern Ocean, with a general warming trend through the Late Jurassic followed by a general cooling trend through the Early Cretaceous. The lowest sea-surface temperatures are recorded from around the Callovian-Oxfordian boundary, an interval identified in Europe as relatively cool, but do not fall below $25^{\circ} \mathrm{C}$. The early Aptian Oceanic Anoxic Event, identified on the basis of published biostratigraphy, total organic carbon and carbon-isotope stratigraphy, records an interval with the lowest, albeit fluctuating Early Cretaceous palaeotemperatures $\left(\sim 26^{\circ} \mathrm{C}\right)$, recalling similar phenomena recorded from $\mathrm{Eu}-$ rope and the tropical Pacific Ocean. Extant belemnite $\delta^{18} \mathrm{O}$ data, assuming an isotopic composition of waters inhabited by these fossils of $-1 \%$ SMOW, give palaeotemperatures throughout the Upper Jurassic-Lower Cretaceous interval that are consistently lower by $\sim 14^{\circ} \mathrm{C}$ than does $\mathrm{TEX}_{86}$ and the molluscs likely record conditions below the thermocline. The long-term, warm climatic conditions indicated by the $\mathrm{TEX}_{86}$ data would only be compatible with the existence of continental ice if appreciable areas of high altitude existed on Antarctica, and/or in other polar regions, during the Mesozoic Era.
\end{abstract}

\section{Introduction}

In order to understand Jurassic and Cretaceous climate, the reconstruction of sea-surface temperatures at high latitudes, and their variation over different time scales, is of paramount importance. A basic division of Phanerozoic climatic modes into "icehouse" and "greenhouse" periods is now commonplace (Fischer, 1982). However, a number of authors have invoked transient icecaps as controls behind eustatic sea-level change during the Mesozoic greenhouse period (e.g. Price, 1999; Stoll and Schrag, 2000; Dromart et al., 2003; Gale et al., 2002; Miller et al., 2003, 2005; Gréselle and Pittet, 2010); others weigh the evidence in favour of a relatively equable tropical to subtropical environment at the poles throughout this interval, although there is evidence for intervals of rapid climate change (e.g. Tarduno et al., 1998; Huber et al., 2002; Bice et al., 2003; Jenkyns, 2003; Moriya et al., 2007; Dera et al., 2011; Littler et al., 2011). Evidence for cool climates derives from oxygen-isotope data from wellpreserved foraminifera from one Upper Cretaceous Atlantic ODP site (Bornemann et al., 2008) and changes in nannofossil assemblages from both low and high latitudes (Mutterlose et al., 2009) and putative Cretaceous glacial deposits and so-called glendonites that formed from the cold-temperature hydrated form of calcium carbonate, ikaite (Kemper, 1987; Frakes and Francis, 1988; de Lurio and Frakes, 1999; Alley and Frakes, 2003). The presence of certain plants, fish species and fossil reptiles, however, rather points towards much warmer polar climates, at least at low altitudes (Nathorst, 1911; Tarduno et al., 1998; Friedman et al., 2003; Vandermark et al., 2007), as do oxygen-isotope values of benthonic and planktonic foraminifera (Huber et al., 1995; Bice et al., 2003). Indeed, Moriya et al. (2007) could find no oxygen-isotope evidence for glaciation during the mid-Cenomanian, an interval suggested to have witnessed glacio-eustatic changes in sea level by Gale et al. (2002). 
The organic geochemical proxy $\mathrm{TEX}_{86}$ ("tetraether index of 86 carbon atoms") offers the advantage of giving estimates of sea-surface temperatures and is applicable to those sediments lacking in carbonate that contain sufficient quantities of immature organic matter (Schouten et al., 2002, 2003; Kim et al., 2010). TEX 86 data from Aptian and Albian organic-rich sediments suggest low-latitude temperatures in the Atlantic and Pacific Ocean in the range 31$36^{\circ} \mathrm{C}$ (Schouten et al., 2003; Forster et al., 2007; Dumitrescu et al., 2006; recalibrated after Kim et al., 2010). Upper Berriasian to lower Barremian organic-rich sediments from the peri-equatorial Atlantic Ocean give similar mid- $30^{\circ} \mathrm{C}$ sea-surface temperatures from $\mathrm{TEX}_{86}$ data (Littler et al., 2011). The highest latitude Cretaceous sediments examined to date are lowermost Maastrichtian carbonate-free organicrich muds from the Arctic Ocean, which yielded a recalibrated mean annual sea-surface temperatures of $\sim 19^{\circ} \mathrm{C}$ (recalibrated from the data of Jenkyns et al., 2004, using the revised temperature calibration of Kim et al., 2010). The longterm evolution of mid-Mesozoic, high-latitude palaeotemperatures in the Southern Hemisphere is here elucidated by analysing DSDP/ODP sediments retrieved from Site 693 and 511 close to Antarctica (Fig. 1). This report extends the application of the $\mathrm{TEX}_{86}$ palaeothermometer back into the Callovian (Middle Jurassic), the oldest sediments from the World Ocean yet analysed for this proxy.

\section{Methods}

Powdered and freeze-dried sediments ( $1-3 \mathrm{~g}$ dry mass) were extracted with dichloromethane (DCM)/methanol (2:1) by using the Dionex accelerated solvent extraction technique. The extracts were separated by $\mathrm{Al}_{2} \mathrm{O}_{3}$ column chromatography using hexane/DCM (9:1), DCM/methanol (95:5) and DCM/methanol (1:1) as subsequent eluents to yield the apolar, tetraether and polar fractions, respectively. The apolar and desulfurized (using Raney Ni) polar fractions were analysed by gas chromatography and gas chromatography/mass spectrometry. The polar fractions were analysed for GDGTs as described in Schouten et al. (2007): separation was achieved on a Prevail Cyano column $(2.1 \times 150 \mathrm{~mm}, 3 \mu \mathrm{m}$, with flow rate at $0.2 \mathrm{ml} \mathrm{min}^{-1}$ ), and single ion monitoring of the $[\mathrm{M}+\mathrm{H}]^{+}$ions (dwell time, $234 \mathrm{~ms}$ ) was used to quantify the GDGTs with 1-4 cyclopentane moieties and calculate the TEX $_{86}$ values following Schouten et al. (2002). These values were converted to sea-surface temperature (SST) according to the equation of Kim et al. (2010):

$\mathrm{SST}=68.4 \times \log \left(\mathrm{TEX}_{86}\right)+38.6$

This calibration, based on analysis of 426 core-top samples and satellite-derived sea-surface temperatures averaged over $10 \mathrm{yr}$, is applicable for regions yielding SST estimates $>15^{\circ} \mathrm{C}$, which is the case for the studied sections. The majority of samples were analysed in duplicate and replicate analysis has shown that the error in $\mathrm{TEX}_{86}$ values is $\sim 0.01$ or $\sim 0.6^{\circ} \mathrm{C}$. The BIT (Branched and Isoprenoid Tetraether Index) of all samples was $<0.1$, indicating a low content of soil-derived organic carbon, and hence minimal bias of TEX 86 -derived palaeotemperatures (cf. Weijers et al., 2006). The apolar fractions of all samples from Site 693 and a subset of samples from Site 511 were studied by GC-MS, which indicated the presence of pristane, phytane, hopanes, $\mathrm{C}_{28}$-dinorhopane, lycopane and sterenes, suggesting that the marine organic matter has mainly a phytoplanktonic source. The ratio of two stereoisomers of $\mathrm{C}_{31}$-homohopanes $(17,21-\beta \beta /[\beta \beta+\alpha \beta])$ is $>0.6$ for all sediments analyzed, indicating that the organic matter is immature and hence suitable for palaeotemperature reconstruction using the $\mathrm{TEX}_{86}$ proxy (cf. Schouten et al., 2004).

Bulk organic isotopes and TOC contents for sediments from Site 511 were determined by decalcifying powdered rock samples with $2 \mathrm{~N}$ hydrochloric acid and analysing the decalcified sediments in duplicate on a Carlo Erba 1112 Flash Elemental Analyser coupled to a Thermofinnigan Delta Plus isotope mass spectrometer. Analytical errors for TOC (Site 693) were generally better than $0.3 \%$; reproducibility of $\delta^{13} \mathrm{C}_{\text {org }}$ was generally $\sim 0.1 \%$ o PDB.

\section{Lithology and stratigraphy}

Material from two sites drilled by the Deep Sea Drilling Project and the Ocean Drilling Program was investigated in this study (Fig. 1): DSDP Site 511, Falkland Plateau, in the South Atlantic, drilled during Leg 71 (palaeolatitude $\sim 60^{\circ} \mathrm{S}$ ); and ODP Site 693A, drilled in the Weddell Sea on the continental slope off East Antarctica (palaeolatitude $\sim 70^{\circ} \mathrm{S}$ ), during Leg 113 (Ludwig and Krasheninikov et al., 1983; Barker et al., 1988). The section drilled on the Falkland Plateau is unusual in that it offers a Middle JurassicLower Cretaceous hemipelagic sedimentary section of black locally laminated organic-rich shale and mudstone, $\sim 140 \mathrm{~m}$ in thickness, containing a rich macrofauna of belemnites, ammonites and bivalves (Basov et al., 1983; Jeletzky, 1983). The section drilled on the Antarctic slope is represented by $\sim 70 \mathrm{~m}$ of Lower Cretaceous hemipelagic black organic-rich silty mudstone (Fig. 2: O'Connell, 1990).

The biostratigraphy of the high-latitude Cretaceous sediments is not unambiguous because the ranges of critical taxa are imperfectly known and certain key stage boundaries are not yet rigorously defined. The organic-rich section of ODP Site 693 (Fig. 2) has yielded planktonic foraminifera of probable late Aptian age (Leckie, 1990); nannofossil data suggest the presence of the uppermost Aptian to lowermost Albian interval, with a stage boundary tentatively fixed at around $453 \mathrm{mbsf}$, although the boundary would be placed higher in the section on some biostratigraphic criteria (Mutterlose and Wise, 1990; Mutterlose et al., 2009). 


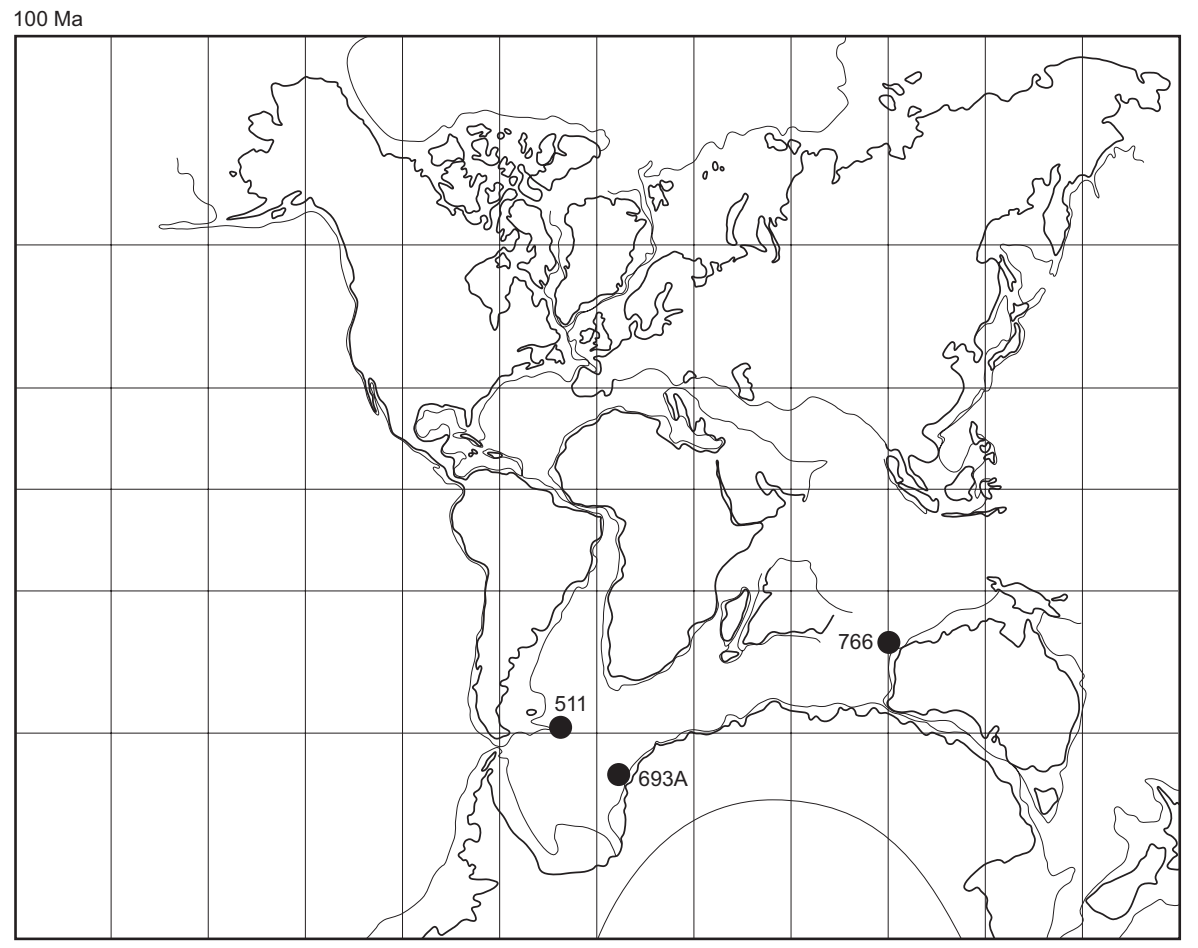

Fig. 1. Map of the mid-Cretaceous world, showing the locations of Site 511 on the Falkland Plateau, Site 693 on the Antarctic shelf, and Site 766 (location includes adjacent Sites 762 and 763) on the Exmouth Plateau, western Australia. Reconstructions after Smith et al. (1981), Mutterlose et al. (2009), O’Connell (1990), Bralower et al. (1994), and Clarke and Jenkyns (1999).

For Site 511, nannofossil biostratigraphy suggests the presence of the uppermost Callovian, Oxfordian and Kimmeridgian-Tithonian stages, an interpretation that is broadly supported by biostratigraphic determinations of molluscan faunas (Jeletzky, 1983) and strontium-isotope ratios from belemnites that, when compared with the global reference curve, suggest the presence of all four stages (Price and Gröcke, 2002). There is no unequivocal nannofossil evidence for the presence of the Berriasian, Valanginian and Hauterivian stages, which implies the presence of a major hiatus within the black shales without any obvious sedimentary expression (Wise, 1983). Whether this putative hiatus is a function of non-deposition or due to large-scale removal of sediment by slumping is unresolved. However, strontiumisotope ratios give values that suggest that the Hauterivian and possibly the Valanginian are represented at this site, at least by those belemnites yielding age-significant geochemical data (Price and Gröcke, 2002). The Barremian and Aptian intervals are recognized by characteristic planktonic foraminiferal faunas (Krasheninnikov and Basov, 1983) and nannofossil data have been used to fix the boundary between the stages at $\sim 555 \mathrm{mbsf}$ (Bralower et al., 1994), an ageassignment that is at odds with that derived from strontiumisotope dating that indicates a Hauterivian-Barremian age as high as $524 \mathrm{mbsf}$ in the core (Price and Gröcke, 2002). The boundary between the lower and upper Aptian is fixed at $508-513 \mathrm{mbsf}$ on the basis of nannofossil and ammonite biostratigraphy (Jeletzky, 1983; Bralower et al., 1993). However, planktonic foraminiferal faunas fix the boundary between the Aptian and Albian stages at $\sim 486 \mathrm{mbsf}$ (Huber et al., 1995), although some authors, using nannofossil dating, have put the contact lower in the section, between 500 and 510 mbsf (Basov et al., 1983; Bralower et al., 1993). A generalized "best fit" stratigraphy, utilizing available biostratigraphic and $\mathrm{Sr}$-isotope data, is utilized in Fig. 3.

\section{TOC and organic carbon-isotope curves from ODP Site 693A and DSDP Site 511}

The total organic-carbon (TOC) curve from Site 693A in the Weddell Sea is unremarkable, indicating values generally lower than $1.5 \%$ over the interval analysed and, apart from peak values at $\sim 456 \mathrm{mbsf}$, shows a decreasing trend towards the top of the interval (Fig. 2). TOC values for the Lower Cretaceous dark shales and mudstones of this site average $\sim 2.5 \%$ (O'Connell, 1990). In the lower part of the investigated section, $\delta^{13} \mathrm{C}_{\text {org }}$ values track close to $-27 \%$ o before rising to $-22 \%$ and then drop back to $\sim-25 \%$ o. This range of values is typical for organic matter in Aptian-Albian black shales in Europe (Menegatti et al., 1998). Given the number of positive and negative excursions in the Aptian and Albian, 


\section{Continental slope, East Antarctica (Site 693A)}
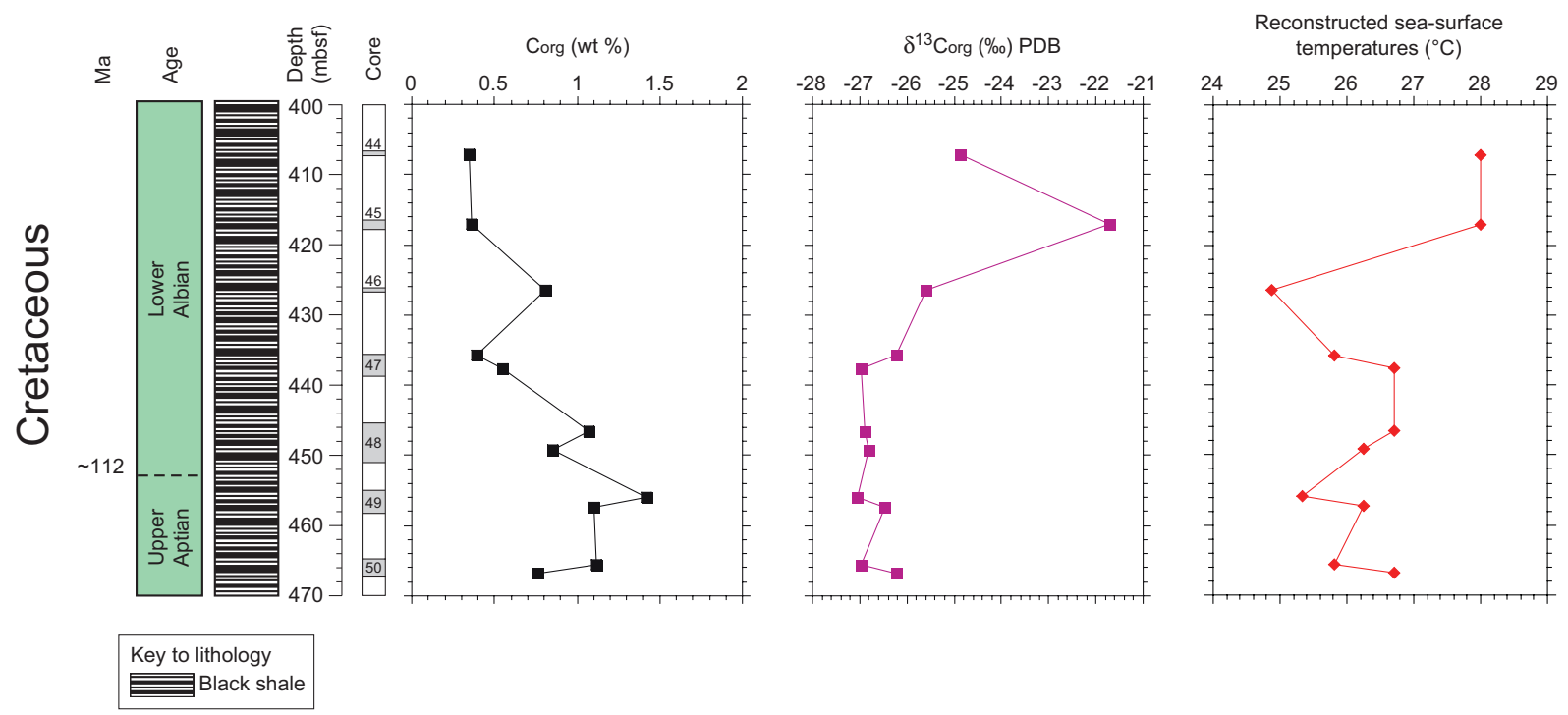

Fig. 2. Geochemical and palaeotemperature data from ODP Site 693 on the Antarctic shelf. Total Organic Carbon (TOC) values mostly lie in the $0.5-1.5 \mathrm{wt} \%$ range; the carbon-isotope values, including the positive excursion, are compatible with the biostratigraphically assigned Aptian-Albian age. Palaeotemperature data, determined using the Kim et al. (2010) calibration, suggest sea-surface temperatures mostly in the $24-28^{\circ} \mathrm{C}$ range. Approximate absolute ages after the time scale of Ogg et al. (2008).

as recorded in $\delta^{13} \mathrm{C}$ carbonate from the Vocontian Trough, south-east France, the isotopic curve from Site 693A has little chemostratigraphic significance, although both negative and positive excursions do occur close to the stage boundary in the French section (Herrle et al., 2004).

TOC values for Site 551 are typically in the $2-6 \%$ range for the majority of samples over the uppermost Jurassiclowest Cretaceous interval (Fig. 3), dropping abruptly to values close to zero around the boundary of the lower and upper Aptian; the organic matter has a relatively high hydrogen index (200-600 mg hydrocarbons per g organic carbon), indicating that it is dominantly marine in nature (Deroo et al., 1983), as borne out by biomarker analysis, which reveals high abundances of steranes and lycopane. Over the same Mesozoic interval, $\delta^{13} \mathrm{C}_{\text {org }}$ values are typically in the range -30 to $-28 \%$, rising into an irregular positive excursion close to the lower-upper Aptian boundary, as fixed biostratigraphically by nannofossils and ammonites (Jeletzky, 1983; Bralower et al., 1993), with a peak value of $-18.5 \%$. By comparison with European sections in Italy and Switzerland, this isotopic signature is characteristic of the middle part of the Aptian stage where a positive shift in $\delta^{13} \mathrm{C}_{\text {org }}$ of $6-7 \%$ o is observed (Menegatti et al., 1998). Biostratigraphy and carbon-isotope stratigraphy are hence in agreement.

\section{Middle Jurassic-Early Cretaceous marine sea-surface temperatures in the Southern Ocean}

TEX $_{86}$-derived sea-surface temperatures for the continental slope off Antarctica (Site 693A), around Aptian-Albian boundary time, fall in the range $24-28^{\circ} \mathrm{C}$ and suggest a warming trend into the early Albian (Fig. 2).

The data from the Falkland Plateau (Site 511) give the first $\mathrm{TEX}_{86}$ palaeotemperature record from the Jurassic and suggest values in the range $26-30^{\circ} \mathrm{C}$, with an overall warming trend, for the latter part of this Period (Fig. 3). Such a general warming trend fits with the overall decline in oxygen-isotope ratios in Upper Jurassic belemnites and oysters from Europe and Russia (Jenkyns et al., 2002; Dera et al., 2011) and palynological evidence from the North Sea (Abbink et al., 2001). Conversely, the Cretaceous section, over the HauterivianEarly Aptian interval, shows an overall cooling trend over a closely similar temperature range $\left(30-26^{\circ} \mathrm{C}\right)$, a pattern also registered in the $\delta^{18} \mathrm{O}$ ratios of fish teeth from France and Switzerland (Pucéat et al., 2003). Comparison with Site 693 over the late Aptian interval suggests that sea-surface temperatures were some $2{ }^{\circ} \mathrm{C}$ warmer at the Falkland Plateau than off Antarctica, in line with assumed palaeolatitudes of the sites. Although the $\mathrm{TEX}_{86}$ temperature estimates carry some uncertainty due to calibration errors $\left(2.5^{\circ} \mathrm{C}\right.$; Kim et al., 2010), potential seasonal biases (e.g. towards summer in high latitudes; discussion in Sluijs et al., 2006) and depth habitat (e.g. towards thermocline temperatures; Lopes dos Santos et al., 2010), these data indicate that, in the Late Jurassic 


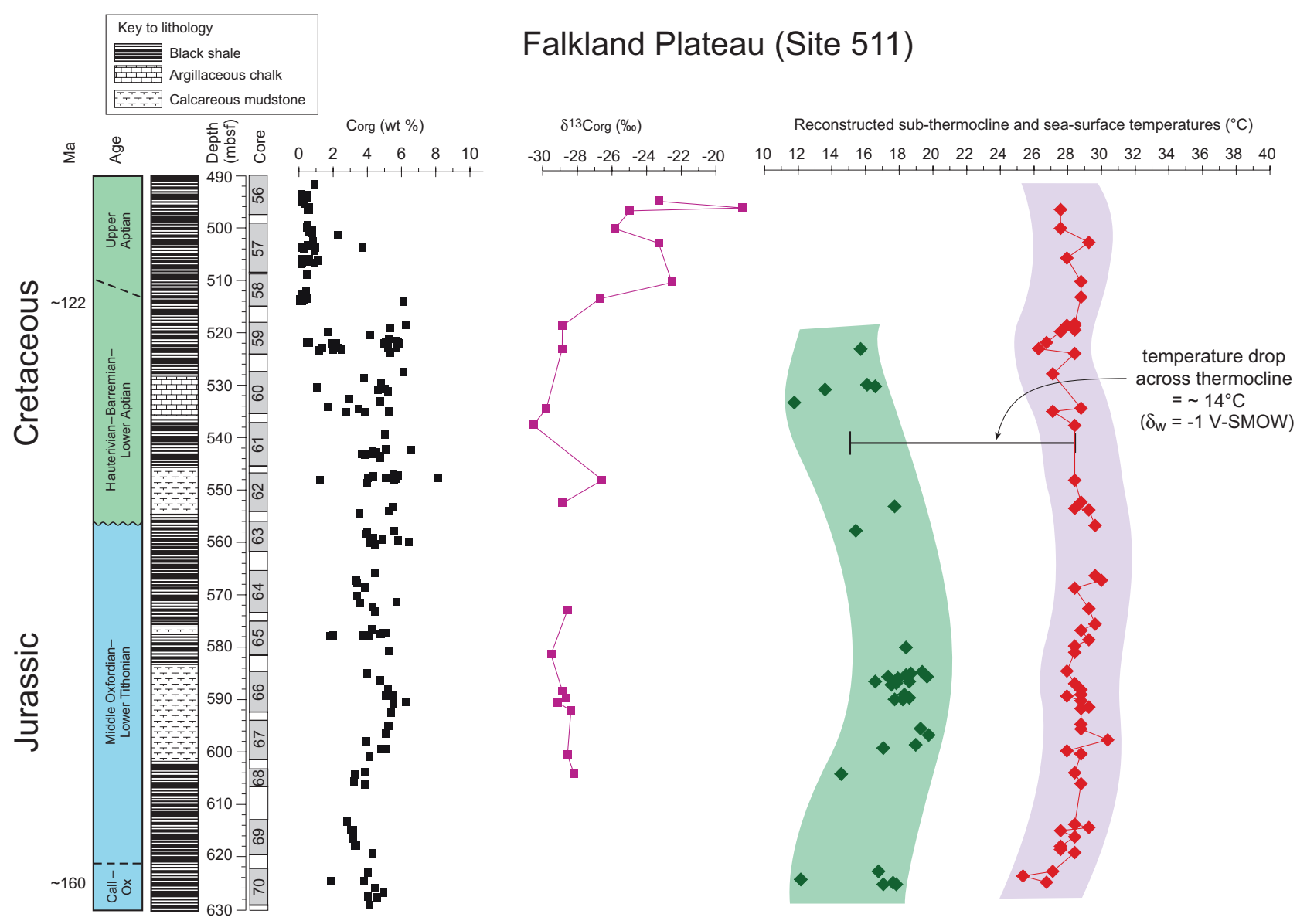

Fig. 3. Geochemical and palaeotemperature data from DSDP Site 511 on the Falkland Plateau. TOC data after Deroo et al. (1983); belemnite $\delta^{18} \mathrm{O}$ palaeotemperature determinations after Price and Gröcke (2002); TEX 86 palaeotemperatures derived from the equation of Kim et al. (2010). Biostratigraphy after numerous sources (see text) integrated with strontium-isotope stratigraphy (Price and Gröcke, 2002). The relatively low values of $\delta^{13}$ Corg passing to relatively high values in the higher parts of the cored section are characteristic of the Aptian stage. The position of the sediments recording the OAE (Fig. 4) is fixed by biostratigraphy (Bralower et al., 1993), as well as by the carbonisotope curve (negative to positive excursion) and the stratigraphic pattern of enrichment in organic carbon, which shows a dramatic fall in the 520-510 mbsf level. The Jurassic part of the section displays an overall warming trend, the Cretaceous part of the section an overall cooling trend; the estimated temperature change across the thermocline is similar through both intervals. Approximate absolute ages after the time scale of Ogg et al. (2008): given points are based on the Callovian-Oxfordian boundary and the early Aptian OAE.

to Early Cretaceous interval, the Southern Hemisphere was likely enjoying a tropical to sub-tropical climate that extended to high latitudes. Indeed, oxygen-isotope data from well-preserved glassy planktonic foraminifers in the Turonian of the Falkland Plateau indicate that unusually high seawater temperatures $\left(30-32^{\circ} \mathrm{C}\right)$ persisted into the Late Cretaceous (Bice et al., 2003).

Given that mid- to late Cretaceous palaeotemperatures from the Arctic Ocean have been estimated to exceed $20^{\circ} \mathrm{C}$, based on $\mathrm{TEX}_{86}$-derived data from a lower Maastrichtian black shale (Jenkyns et al., 2004), it is difficult to see how the Cretaceous world could have hosted appreciable amounts of ice, unless it was stored at high altitude on Antarctica and/or other polar sites.

\section{Reconstruction of the Jurassic-Cretaceous thermocline in the Southern Oceans}

Because Site 511 offers a rich macrofossil assemblage, including ammonites, bivalves and belemnites (Jeletzky, 1983), palaeotemperature data can be extracted from the oxygen-isotope ratios of the skeletal carbonate. The oxygenisotope data from belemnites, however, must represent temperatures below the thermocline, since in one critical Maastrichtian (uppermost Cretaceous) outcrop on the Antarctic peninsula, where these fossils co-exist with benthic and planktonic foraminifera, the $\delta^{18} \mathrm{O}$ values of the molluscs overlap with those of the bottom-dwelling microfossils (Dutton et al., 2007). In another study of Callovian (Middle Jurassic) claystones from southern Britain, the $\delta^{18} \mathrm{O}$ values 


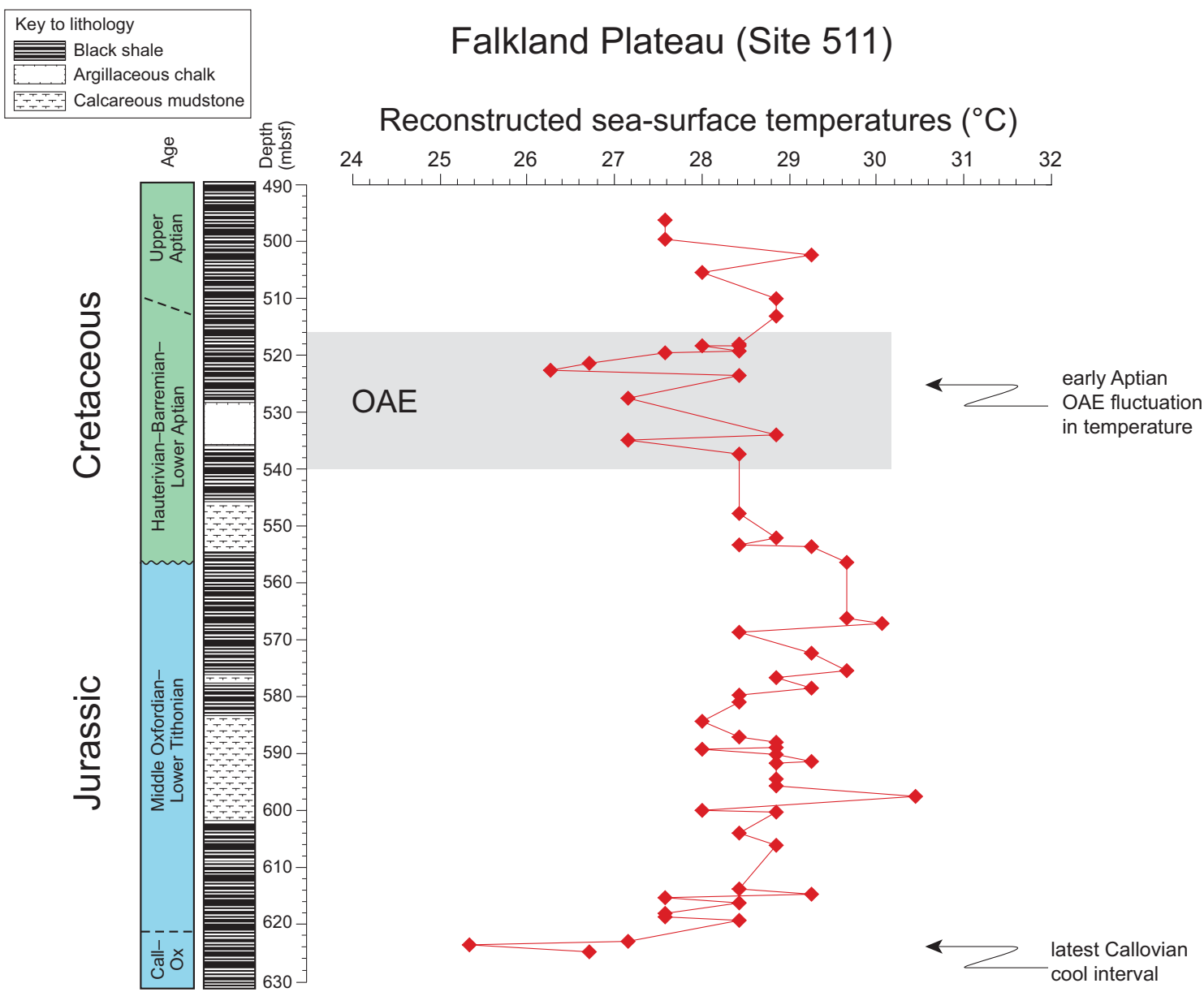

Fig. 4. Detailed illustration of sea-surface palaeotemperature evolution for the Middle Jurassic-Lower Cretaceous section on the Falkland Plateau (DSDP Site 511), using the equation of Kim et al. (2010). The evidence for drops in palaeotemperature in the late Callovian, early Aptian (after the onset of the OAE) and late Aptian conforms to globally recognized patterns.

of belemnites were found to overlap with those of coexisting benthonic bivalves (Anderson et al., 1994), similarly arguing for the fact that belemnites do not record sea-surface or even mixed-layer temperatures, despite their long-term application to marine Mesozoic palaeoclimatological studies (Urey et al., 1951; Lowenstam and Epstein, 1954).

Interpretation of belemnite habitat as relatively deep nektonic or nektobenthonic is critical as it bears directly on the $\delta^{18} \mathrm{O}$ SMOW value of ambient seawater chosen for the palaeotemperature equation. The "canonical" $\delta^{18} \mathrm{O}$ value of $-1 \%$ SMOW for Jurassic-Cretaceous seawater (Shackleton and Kennett, 1975) was used by Price and Gröcke (2002) to calculate palaeotemperatures from the belemnites from Site 511. Adoption of a $\delta^{18} \mathrm{O}$ SMOW value of 0 , as in today's ocean, would warm such palaeotemperatures by $\sim 4^{\circ} \mathrm{C}$ but such a calculation is clearly not applicable to a world lacking substantial land-based polar ice. On the contrary, the presentday evaporation-precipitation balance of the global ocean is such as to lower the $\delta^{18} \mathrm{O}$ SMOW values of high-latitude marine surface waters: a value of $-1.5 \%$ o has been considered appropriate for the Cretaceous of Site 511 (Bice et al., 2003), which would decrease temperatures by $\sim 2{ }^{\circ} \mathrm{C}$ with respect to those calculated using a $\delta^{18} \mathrm{O}$ SMOW value of $-1 \%$. Given the evidence, from North American paleosol sphaerosiderites, for an accelerated Albian hydrological cycle with greater precipitation and cross-latitude oxygenisotope fractionation than today (Ufnar et al., 2004), the $\delta^{18} \mathrm{O}$ SMOW values of near-surface high-latitude marine waters might well have been lower than $-1.5 \%$. However, these considerations would apply primarily to the lower density near-surface layers of the ocean influenced by mixing of rainwater and seawater, and belemnites undoubtedly dwelled at greater depths. Hence, the $\delta^{18}$ O SMOW value of $-1 \%$ is deemed most appropriate for calculation of belemnite palaeotemperatures, but the calculated values should be considered as maxima.

Comparison of the reconstructed marine palaeotemperatures from belemnites with those determined from the $\mathrm{TEX}_{86}$ 
proxy allows the temperature drop across the thermocline to be reconstructed. As shown in Fig. 3, the drop in temperature across the mixed layer was remarkably close to $14^{\circ} \mathrm{C}$ during the entire Late Jurassic-Early Cretaceous interval on the Falkland Plateau. The belemnite palaeotemperatures from Site 511 are comparable to those determined from highlatitude Upper Jurassic and Lower Cretaceous sites in the Southern Hemisphere such as James Ross Island, Antarctica and western Australia, which give figures in the $10-15^{\circ} \mathrm{C}$ range (Ditchfield et al., 1994; Pirrie et al., 1995). A vertical thermal gradient of up to $14^{\circ} \mathrm{C}$, based on oxygen-isotope data of coexisting fossil fish and brachiopods, has also been reconstructed from Middle to Upper Jurassic sediments from northern and southern France (Picard et al., 1998).

Palaeotemperature offsets in the range $5-15^{\circ} \mathrm{C}$, based on $\mathrm{TEX}_{86}$ determinations (warmer) and belemnite $\delta^{18} \mathrm{O}$ values (cooler), are similarly recorded from the Barremian sediments of north Germany (Mutterlose et al., 2010). These figures indicate the approximate level of increase needed to convert belemnite palaeotemperatures into sea-surface values. Such figures are considerably greater than the $2-2.5^{\circ} \mathrm{C}$ sea-bottom to sea-surface difference suggested by Zakharov et al. (2011), or $8^{\circ} \mathrm{C}$ suggested by Moriya et al. (2003), for Cretaceous ammonites, based on their assumed nektobenthonic ecology, but is in line with the relative depth habitat inferred for these two types of cephalopod, with belemnites typically inhabiting deeper, colder water (Anderson et al., 1994).

Because oxygen-isotope values from planktonic foraminifera are typically reset by recrystallization on the sea floor, hence producing spuriously low temperatures (Pearson et al., 2001), benthonic foraminiferal records are potentially more reliable indices of ambient conditions. Basal Albian benthic foraminifera from Site 511 suggest sub-thermocline temperatures of $\sim 13{ }^{\circ} \mathrm{C}$ (Fassell and Bralower, 1999), in line with reconstructed belemnite palaeotemperatures established in the Barremian-Aptian part of the core (Fig. 3). The $\delta^{18} \mathrm{O}$ record of upper Aptian bulk and fine-fraction nannofossil carbonates cored from off western Australia (ODP Sites 762, 763, 766 (Fig. 1): palaeolatitude $\sim 53-54^{\circ} \mathrm{S}$ ) has yielded estimated palaeotemperatures as low as $\sim 12{ }^{\circ} \mathrm{C}$ (Clarke and Jenkyns, 1999), which suggests either that the nannofossils mostly inhabited waters deeper than the thermocline and/or that sea-floor re-equilibration must have influenced this material as well.

There is no reason to think that sub-thermocline waters necessarily had an origin at the surface around Antarctica; more probably they reflect the typical temperature structure of a Mesozoic water column heated by insolation from above.

\section{The early Aptian Oceanic Anoxic Event on the Falkland Plateau}

The early Aptian Oceanic Anoxic Event (OAE1a or Selli Event), defining a period of unusually widespread oxygendepleted waters accompanied by widespread deposition of black shales, has been recorded in all major ocean basins (Schlanger and Jenkyns, 1976; Arthur et al., 1990; Jenkyns, 2003, 2010). The record of the OAE has been identified at Site 511 on the Falkland Plateau on biostratigraphic grounds (Bralower et al., 1994). Because organic-rich sediments characterize much of the section, isolating the interval affected by the OAE on lithological grounds alone is not immediately obvious. A defining characteristic of the OAE in sections worldwide is the presence of a negative carbonisotope excursion followed by a positive excursion that extends into the late Aptian (Weissert and Lini, 1991; Jenkyns, 1995; Menegatti et al., 1998; Luciani et al., 2001; Bellanca et al., 2002; Malkoč et al., 2010). Typically, the positive $\delta^{13} \mathrm{C}$ excursion extends stratigraphically well above the most organic-rich horizon, across which carbon-isotope values are relatively constant. The suggested level on the Falkland Plateau that records the early Aptian OAE, as fixed by biostratigraphy, TOC (note the dramatic drop in values passing up-section) and $\delta^{13} \mathrm{C}_{\text {org }}$ stratigraphy (Fig. 3), is illustrated in Fig. 4. The reconstructed palaeotemperatures at this site range between 26 and $29^{\circ} \mathrm{C}$ during the $\mathrm{OAE}$ and indicate a drop of $\sim 3{ }^{\circ} \mathrm{C}$ at the level where a relative maximum TOC value is recorded. Although the early Aptian OAE represents an interval of relative warmth (Jenkyns, 2003), two cooling episodes of $\sim 4{ }^{\circ} \mathrm{C}$, based on $\mathrm{TEX}_{86}$ records, are recorded from Shatsky Rise in the north Pacific Ocean (ODP Site 1207) where temperatures range between 32 and $37^{\circ} \mathrm{C}(\mathrm{Du}-$ mitrescu et al., 2006; recalculated using the calibration of Kim et al., 2010): the drops in temperature, assumed to be global in nature, are attributed to drawdown of carbon dioxide due to enhanced marine organic-carbon burial and continental weathering during the OAE (Jenkyns, 2010). Given that the Shatsky Rise occupied a peri-equatorial position during the early Aptian, the Equator-to-pole sea-surface temperature gradient during the $\mathrm{OAE}$ was $\sim 10^{\circ} \mathrm{C}$ or less. A drop in temperature of $\sim 3^{\circ} \mathrm{C}$ during the early phase of this event has been suggested for a mid-latitude site (southern France), based on oxygen-isotope data from well-preserved pelagic limestones and marlstones (Kuhnt et al., 2011). A cooling event is also recorded in the early Aptian based on the oxygen-isotopic composition of enamel in fish teeth from central and northern Europe (Pucéat et al., 2003). The different sedimentary archives, and the range of palaeolatitudes represented, underscore the global nature of this fall in temperature. 


\section{Evidence for Jurassic-Cretaceous "cold snaps" in the Southern Ocean}

The Callovian-Oxfordian boundary interval has been identified in Europe as a relatively cool interval, based on a number of independent criteria. Oxygen-isotope data from English and Russian belemnites indicate a drop in temperature commencing in the latest Callovian (Jenkyns et al., 2002), as do sharks' teeth from England, France and Switzerland (Lécuyer et al., 2003). Accompanying the proposed drop in temperature $\left(\sim 7^{\circ} \mathrm{C}\right.$ in Northern Hemisphere mid-latitudes from shark-teeth data), there is evidence for simultaneous invasion of boreal ammonite species into lower latitude zones and, because regional facies analysis suggests sea-level fall across the stage boundary, it has been suggested that this interval records build-up of continental polar ice (Dromart et al., 2003). The TEX 86 palaeotemperature data from the Falkland Plateau (Fig. 3) indicate an observed minimum of $\sim 25-26^{\circ} \mathrm{C}$ around Callovian-Oxfordian boundary time, followed by a $2-3^{\circ} \mathrm{C}$ rise. Because the lowest value lies close to the base of the cored section, neither an absolute minimum nor an absolute rise in temperature can be determined, but clearly the $\mathrm{TEX}_{86}$ data, even considering the uncertainties in palaeotemperature estimates, are not compatible with glaciation at sea level on Antarctica and adjacent continents.

Cold snaps in the Valanginian and around the AptianAlbian boundary have been proposed on the basis of the presence of glendonites (pseudomorphs of the cool-temperature form of hydrated calcium carbonate, ikaite) in sediments of this age cropping out in the Sverdrup Basin of Arctic Canada and Svalbard (Kemper, 1987; Price and Nunn, 2010). Glendonites are also reported from Upper Aptian shales in the Eromanga Basin of Australia (Frakes and Francis, 1988; de Lurio and Frakes, 1999). These occurrences are associated with centimetre-scale clasts that have been interpreted as icerafted but which could equally well be interpreted as treerafted (Bennett and Doyle, 1996). Ikaite typically forms at temperatures no greater than $\sim 7^{\circ} \mathrm{C}$, although it may be stabilized at higher temperatures in phosphate-rich interstitial waters such as characterize organic-rich sediments (de Lurio and Frakes, 1999). As an early diagenetic product growing by displacement within sediment, however, it clearly offers little in the way of palaeotemperature data for the sea surface as it forms in water depths below the mixed layer. $\mathrm{TEX}_{86}$ data from the Valanginian of Site 766 (Fig. 1) give sea-surface temperatures consistently in the $25-26^{\circ} \mathrm{C}$ range (Littler et al., 2011). Hence, this proxy shows consistently warm, high-latitude sea-surface temperatures throughout the Late Jurassic and Early Cretaceous.

Nannofossil data from both low- and high-latitude sites around the Aptian-Albian boundary show a decline in Tethyan taxa and invasion of more boreal forms, indicative of cooling, and diatoms also appeared in high-latitude sites in both Northern and Southern Hemispheres during this interval (Mutterlose et al., 2009). Data from the Falkland Plateau do not illustrate any notable drop in temperature in the Late Aptian, although such a phenomenon may not have been captured by the TEX 86 profile because the use of this proxy is precluded by the lack of black shales extending into the Albian.

In conclusion, although accumulation of ice at high altitude on Antarctica or other polar regions cannot be ruled out and indeed can be successfully modelled (Donnadieu et al., 2011), there is an absence of critical evidence. As far as Antarctica is concerned, the pre-Cenozoic elevation is poorly known. Estimates of 500-1200 $\mathrm{m}$ have been suggested for the Transantarctic Mountains, with most of the uplift having taken place since the Jurassic (Fitzgerald, 2002), but such an area of modest Mesozoic relief only represents a small portion of a very large continent. The fact remains that these reconstructed warm high-latitude sea-surface palaeotemperatures are difficult to reconcile with the notion of major "icehouse" interludes for a period extending over $\sim 40$ million yr (Middle Jurassic to Early Cretaceous).

\section{Supplementary material related to this article is available online at: http://www.clim-past.net/8/215/2012/ cp-8-215-2012-supplement.pdf.}

Acknowledgements. We thank Antje Müller for performing some of the analytical work. A constructive review by C. Lecuyer, comments from an anonymous reviewer, and a flamboyant critique by D. Gröcke led to substantial revision and improvement of the manuscript. Samples were obtained courtesy of DSDP/ODP/IODP.

Edited by: L. Beaufort

\section{References}

Abbink, O., Targarona, J., Brinkhuis, H., and Visscher, H.: Late Jurassic to earliest Cretaceous palaeoclimatic evolution of the southern North Sea, Global Planet. Change, 30, 231-256, 2001.

Alley, N. F. and Frakes, L.: First known Cretaceous glaciation: Livingston Tillite Member of the Cadna-owie Formation, South Australia, Aust. J. Earth Sci., 50, 139-144, 2003.

Anderson, T. F., Popp, B. N., Williams, A. C., Ho, L.-Z., and Hudson, J. D.: The stable isotopic records of fossils from the Peterborough Member, Oxford Clay Formation (Jurassic), UK: palaeoenvironmental implications, J. Geol. Soc. London, 151, 125-138, 1994.

Arthur, M. A., Jenkyns, H. C., Brumsack, H.-J., and Schlanger, S. O.: Stratigraphy, geochemistry, and paleoceanography of organic carbon-rich Cretaceous sequences, in Cretaceous Resources, Events and Rhythms, edited by: Ginsburg, R. N. and Beaudoin, B., 75-119, NATO ASI Ser., 304, Kluwer Acad., Dordrecht, Netherlands, 1990.

Barker, P. F., Kennett, J. P., O’Connell, S., Berkowitz, S., Bryant, W. R., Burkle, L. H., Egeberg, P. K., Fütterer, D. K., Gersonde, R. E., Golovchenko, X., Hamilton, N., Lawver, L., Lazarus, D. 
B., Lonsdale, M., Mohr, B., Nagao, T., Pereira, C. P. G., Pudsey, C. J., Robert, C. M., Schandl, E., Spiess, V., Stott, L. D., Thomas, E., Thompson, K. F. M., and Wise, S. W.: Site 693, in: Proc. Ocean Drill. Program., Initial Reports, 113, 329-447, Ocean Drilling Program, College Station, Texas, 1988.

Basov, I. A., Ciesielski, P. F., Krasheninnikov, V. A., Weaver, F. M., and Wise, S. W.: Biostratigraphic and paleontological synthesis: Deep Sea Drilling Project Leg 71, Falkland Plateau and Argentine Basin, in Initial Reports of the Deep Sea Drilling Project, edited by: Ludwig, W. J., Krasheninnikov, V. A., Basov, I. A., Bayer, U., Bloemendal, J., Bornhold, B., Ciesielski, P. F., Goldstein, E. H., Robert, C., Salloway, J., Usher, J. L., von der Dick, H., Weaver, F. M., and Wise, S. W., 71, Part 1, 445-460, US Government Printing Office, Washington, 1983.

Bellanca, A., Erba, E., Neri, R., Premoli Silva, I., Sprovieri, M., Tremolada, F., and Verga, D.: Palaeoceanographic significance of the Tethyan "Livello Selli" (Early Aptian) from the Hybla Formation, northwestern Sicily: biostratigraphy and high-resolution chemostratigraphic records, Palaeogeogr. Palaeocl., 185, 175196, 2002.

Bennett, M. R. and Doyle, P.: Global cooling inferred from dropstones in the Cretaceous: fact or wishful thinking?, Terra Nova, 8, 182-185, 1996.

Bice, K. L., Huber, B. T., and Norris, R. D.: Extreme polar warmth during the Cretaceous greenhouse? Paradox of the late Turonian $\delta^{18} \mathrm{O}$ record at Deep Sea Drilling Project Site 511, Paleoceanography, 18, 1031, doi:10.1029/2002PA000848, 2003.

Bornemann, A., Norris, R. D., Friedrich, O., Beckmann, B., Schouten, S., Sinninghe Damsté, J. S., Vogel, J., Hofman, P., and Wagner, T.: Isotopic evidence for glaciation during the Cretaceous super-greenhouse, Science, 319, 189-192, 2008.

Bralower, T. J., Sliter, W. V., Arthur, M. A., Leckie, R. M., Allard, D., and Schlanger, S. O.: Dysoxic/anoxic episodes in the AptianAlbian (Early Cretaceous), in The Mesozoic Pacific: Geology, Tectonics, and Volcanism, edited by: Pringle, M. S., Sager, W. W. Sliter, W. V., and Stein, S., 5-37, Geophys. Monographic Ser., 77, American Geophysical Union, Washington, DC, 1993.

Bralower, T. J., Arthur, M. A., Leckie, R. M., Sliter, W. V., Allard, D., and Schlanger, S. O.: Timing and paleoceanography of oceanic dysoxia/anoxia in the Late Barremian to Early Aptian (Early Cretaceous), Palaios, 9, 335-369, 1994

Clarke, L. J. and Jenkyns, H. C.: New oxygen-isotope evidence for long-term Cretaceous climate change in the Southern Hemisphere, Geology, 27, 699-702, 1999.

De Lurio, J. L. and Frakes, L. A.: Glendonites as a paleoenvironmental tool: Implications for early Cretaceous high latitude climates in Australia, Geochim. Cosmochim. Ac., 63, 1039-1048, 1999.

Dera, G., Brigaud, B., Monna, F., Laffont, R., Pucéat, E., Deconinck, J.-F., Pellengard, P., Joachimski, M. M., and Durlet, C.: Climatic ups and downs in a disturbed Jurassic world, Geology, 39, 215-218, 2011.

Deroo, G., Herbin, J. P., and Roucaché, J.: Organic geochemistry of Upper Jurassic-Cretaceous sediments from Site 511, Leg 71, western South Atlantic, in Initial Reports of the Deep Sea Drilling Project, edited by: Ludwig, W. J., Krasheninnikov, V. A., Basov, I. A., Bayer, U., Bloemendal, J., Bornhold, B., Ciesielski, P. F., Goldstein, E. H., Robert, C., Salloway, J., Usher, J. L., von der Dick, H., Weaver, F. M., and Wise, S. W., 71, Part 2,
1001-1013, US Government Printing Office, Washington, 1983. Ditchfield, P. W., Marshall, J. D., and Pirrie, D.: High latitude palaeotemperature variation: New data from the Tithonian to Eocene of James Ross Island, Antarctica, Palaeogeogr. Paleocl., 107, 79-101, 1994.

Donnadieu, Y, Dromart, G., Goddéris, Y., Pucéat, E., Brigaud, B., Dera, G., Dumas, C., and Olivier, N.: A mechanism for brief glacial episodes in the Mesozoic greenhouse, Paleoceanography, 26, PA3212, doi:10.1029/2010PA002100, 2011.

Dromart, G., Garcia, J.-P., Picard, S., Atrops, F., Lécuyer, C., and Sheppard, S. M. S.: Ice age at the Middle-Late Jurassic transition?, Earth Planet. Sc. Lett., 213, 205-220, 2003.

Dumitrescu, M., Brassell, S. C. Schouten, S., Hopmans, E. C., and Sinninghe Damsté, J. S.: Instability in tropical Pacific seasurface temperatures during the early Aptian, Geology, 34, 833836, 2006.

Dutton, A., Huber, B. T., Lohmann, K. C., and Zinsmeister, W. J.: High-resolution stable isotope profiles of a dimitobelid belemnite: implications for paleodepth habitat and late Maastrichtian climate seasonality, Palaios, 22, 642-650, 2007.

Fassell, M. L. and Bralower, T. J.: Warm equable mid-Cretaceous: Stable isotope evidence, in Evolution of the Cretaceous OceanClimate System, edited by: Barrera, E. and Johnson, C., Spec. Pap. Geol. Soc. Am., 332, 121-142, 1999.

Fischer, A. G.: Long-term climatic oscillations recorded in stratigraphy, in Climate in Earth History, Studies in Geophysics, National Academy Press, Washington, 1982.

Fitzgerald, P.: Tectonics and landscape evolution of the Antarctic plate since the breakup of Gondwana, with an emphasis on the West Antarctic Rift System and the Transantarctic Mountains, in Antarctica at the close of a Millennium, 8th International Symposium on Antarctic Earth Sciences, edited by: Gamble, J. A., Skinner, D. N. B., and Henrys, S., Roy. Soc. New Zealand Bull., 35, 453-469, 2002.

Forster, A., Schouten, S., Baas, M., and Sinninghe Damsté, J. S.: Mid-Cretaceous (Albian-Santonian) sea surface temperature record of the tropical Atlantic Ocean, Geology, 35, 919-922, 2007.

Frakes, L. A. and Francis, J. E.: A guide to Phanerozoic cold polar climates from high-latitude ice-rafting in the Cretaceous, Nature, 333, 547-549, 1988.

Friedman, M., Tarduno, J. A., and Brinkman, D. B.: Fossil fishes from the high Canadian Arctic: further palaeobiological evidence for extreme climatic warmth during the Late Cretaceous (Turonian-Coniacian), Cret. Res., 24, 615-632, 2003.

Gale, A. S., Hardenbol, J., Hathway, B., Kennedy, W. J., Young, J. R., and Phansalkar, V.: Global correlation of Cenomanian (Upper Cretaceous) sequences: Evidence for Milankovitch control on sea level, Geology, 30, 291-294, 2002.

Gréselle, B. and Pittet, B.: Sea-level reconstructions from the PeriVocontian Zone (South-east France) point to Valanginian glacioeustasy, Sedimentology, 57, 1640-1684, 2010.

Herrle, J. O., Kößler, P., Friedrich, O., Erlenkeuser, H., and Hemleben, C.: High-resolution carbon isotope records of the Aptian to Lower Albian from SE France and the Mazagan Plateau (DSDP Site 545): A stratigraphic tool for paleoceanographic and paleobiologic reconstruction, Earth Planet. Sc. Lett., 218, 149$161,2004$.

Huber, B. T., Hodell, D. A., and Hamilton, C. P.: Mid- to Late Cre- 
taceous climate of the southern high latitudes. Stable isotopic evidence for minimal equator-to-pole thermal gradients, Bull. Geol. Soc. Am., 107, 1164-1191, 1995.

Huber, B. T., Norris, R. D., and MacLeod, K. G.: Deep-sea paleotemperature record of extreme warmth during the Cretaceous, Geology, 30, 123-126, 2002.

Jeletzky, J. A.: Macroinvertebrate paleontology, biochronology, and paleoenvironments of Lower Cretaceous and Upper Jurassic rocks, Deep Sea Drilling Hole 511, Eastern Falkland Plateau, in Initial Reports of the Deep Sea Drilling Project, edited by: Ludwig, W. J., Krasheninnikov, V. A., Basov, I. A., Bayer, U., Bloemendal, J., Bornhold, B., Ciesielski, P. F., Goldstein, E. H., Robert, C., Salloway, J., Usher, J. L., von der Dick, H., Weaver, F. M., and Wise, S. W., 71, Part 2, 951-975, US Government Printing Office, Washington, 1983.

Jenkyns, H. C.: Carbon-isotope stratigraphy and paleoceanographic significance of the Lower Cretaceous shallow-water carbonates of Resolution Guyot, Mid-Pacific Mountains, in: Proc. Ocean Drill. Program, Sci. Results, edited by: Winterer, E. L., Sager, W. W., Firth, J. V., Sinton, J. M., 143, Ocean Drilling Program, College Station, Texas, 99-104, 1995.

Jenkyns, H. C.: Evidence for rapid climate change in the MesozoicPalaeogene greenhouse world, Philos. T. Roy. Soc. A, 361, 18851916, 2003.

Jenkyns, H. C.: Geochemistry of Oceanic Anoxic Events, Geochem. Geophy. Geosy., 11, Q03004, doi:10.1029/2009GC002788, 2010.

Jenkyns, H. C., Jones, C. E., Gröcke, D. R., Hesselbo, S. P., and Parkinson, D. N.: Chemostratigraphy of the Jurassic System: applications, limitations and implications for palaeoceanography, J. Geol. Soc. London, 159, 351-378, 2002.

Jenkyns, H. C., Forster, A., Schouten, S., and Sinninghe Damsté, J. S.: High temperatures in the Late Cretaceous Arctic Ocean, Nature, 432, 888-892, 2004.

Kemper, E.: Das Klima der Kreidezeit, Geol. Jahrbuch A, 96, 5$185,1987$.

Kim, J.-H., van der Meer, J., Schouten, S., Helmke, P., Willmott, V., Sangiorgi, F., Koç, N., Hopmans, E. C., and Sinninghe Damsté, J. S.: New indices and calibrations derived from the distribution of crenarchaeal isoprenoid tetraether lipids: Implications for past sea surface temperature reconstructions, Geochim. Cosmochim. Ac., 74, 4639-4654, 2010.

Krasheninnikov, V. A. and Basov, I. A.: Stratigraphy of Cretaceous sediments of the Falkland Plateau based on planktonic foraminifers, Deep Sea Drilling Project Leg 71, in Initial Reports of the Deep Sea Drilling Project, edited by: Ludwig, W. J., Krasheninnikov, V. A., Basov, I. A., Bayer, U., Bloemendal, J., Bornhold, B., Ciesielski, P. F., Goldstein, E. H., Robert, C., Salloway, J., Usher, J. L., von der Dick, H., Weaver, F. M., and Wise, S. W., 71, Part 2, 789-820, US Government Printing Office, Washington, 1983.

Kuhnt, W., Holbourn, A., and Moullade, M.: Transient global cooling at the onset of early Aptian oceanic anoxic event (OAE) 1a, Geology, 39, 323-326, 2011.

Leckie, R. M.: Middle Cretaceous planktonic foraminifers of the Antarctic margin: Hole 693A, ODP Leg 113, in: Proc. Ocean Drill. Program, Sci. Results, edited by: Barker, P. F., Kennett, J. P., O'Connell, S., Berkowitz, S., Bryant, W. R., Burkle, L. H., Egeberg, P. K., Fütterer, D. K., Gersonde, R. E., Golovchenko,
X., Hamilton, N., Lawver, L., Lazarus, D. B., Lonsdale, M., Mohr, B., Nagao, T., Pereira, C. P. G., Pudsey, C. J., Robert, C. M., Schandl, E., Spiess, V., Stott, L. D., Thomas, E., Thompson, K. F. M., and Wise, S. W., 113, 319-323, Ocean Drilling Program, College Station, Texas, 1990.

Lécuyer, C., Picard, S., Garcia, J.-P., Sheppard, S. M. F., Grandjean, P., and Dromart, G.: Thermal evolution of Tethyan surface waters during the Middle-Late Jurassic: Evidence from $\delta^{18} \mathrm{O}$ values of marine fish teeth, Paleoceanography, 18, 1076, doi:10.1029/2002PA000863, 2003.

Littler, K., Robinson, S. A., Bown, P. R., Nederbragt, A. J., and Pancost, R. D.: High sea-surface temperatures during the Early Cretaceous Epoch, Nat. Geosci., 4, 169-172, 2011.

Lopes dos Santos, R., Prange, M., Castañeda, I. S., Schefuß, E., Mulitza, S., Schulz, M., Niedermeyer, E. M., Sinninghe Damsté, J. S., and Schouten, S.: Glacial-interglacial variability in Atlantic Meridional Overturning Circulation and thermocline adjustments in the tropical North Atlantic, Earth Plan. Sc. Lett., 300, 407-414, 2010.

Lowenstam, H. A. and Epstein, S.: Paleotemperatures of the postAptian Cretaceous as determined by the oxygen isotope method, J. Geol., 62, 207-248, 1954.

Luciani, V., Cobianchi, M., Jenkyns, H. C.: Biotic and geochemical response to anoxic events: the Aptian pelagic succession of the Gargano Promontory (Southern Italy), Geol. Mag., 138, 277298, 2001.

Ludwig, W. J., Krasheninnikov, V. A., Basov, I. A., Bayer, U., Bloemendal, J., Bornhold, B., Ciesielski, P. F., Goldstein, E. H., Robert, C., Salloway, J., Usher, J. L., von der Dick, H., Weaver, F. M., and Wise, S. W.: Site 511, in Initial Reports of the Deep Sea Drilling Project, 71, Part 1, 21-109, US Government Printing Office, Washington, 1983.

Malkoč, M., Mutterlose, J., and Pauly, S.: Timing of the Early Aptian $\delta^{13} \mathrm{C}$ excursion in the Boreal Realm, Newsl. Stratigr., 43, 251-273, 2010.

Menegatti, A. P., Weissert, H., Brown, R. S., Tyson, R. V, and Farrimond, P.: High-resolution $\delta^{13} \mathrm{C}$ stratigraphy through the early Aptian "Livello Selli" of the Alpine Tethys, Paleoceanography, 13, 530-545, 1998.

Miller, K. G., Sugarman, P. J., Browning, J. V., Kominz, M. A., Hernández, J. C., Olsson, R. K., Wright, J. D., Feigenson, M. D., and Van Sickel, W.: Late Cretaceous chronology of large, rapid sea-level changes: Glacioeustasy during the greenhouse world, Geology, 31, 585-588, 2003.

Miller, K. G., Wright, J. D., and Browning, J. V.: Visions of ice sheets in a greenhouse world, Mar. Geol., 217, 215-231, 2005.

Moriya, K., Nishi, H., Kawahata, H., Tanabe, K., and Takayanagi, Y.: Demersal habitat of Late Cretaceous ammonoids: Evidence from oxygen isotopes for the Campanian (Late Cretaceous) northwestern Pacific thermal structure, Geology, 31, 167-170, 2003.

Moriya, K., Wilson, P. A., Friedrich, O., Erbacher, J., and Kawahata, H.: Testing for ice sheets during the mid-Cretaceous greenhouse using glassy foraminiferal calcite from the midCenomanian tropics on Demerara Rise, Geology, 35, 615-618, 2007.

Mutterlose, J. and Wise Jr., S. W.: Lower Cretaceous nannofossil biostratigraphy of ODP Leg 113 Holes 692B and 693A, continental slope off East Antarctica, Weddell Sea, in: Proc. Ocean 
Drill. Program, Sci. Results, edited by: Barker, P. F., Kennett, J. P., O'Connell, S., Berkowitz, S., Bryant, W. R., Burkle, L. H., Egeberg, P. K., Fütterer, D. K., Gersonde, R. E., Golovchenko, X., Hamilton, N., Lawver, L., Lazarus, D. B., Lonsdale, M., Mohr, B., Nagao, T., Pereira, C. P. G., Pudsey, C. J., Robert, C. M., Schandl, E., Spiess, V., Stott, L. D., Thomas, E., Thompson, K. F. M., and Wise, S. W., 113, 325-351, Ocean Drilling Program, College Station, Texas, 1990.

Mutterlose, J., Bornemann, A., and Herrle, J.: The Aptian-Albian cold snap: Evidence for "mid" Cretaceous icehouse interludes, Neues Jahrb. Geol. P.-A., 252, 217-225, 2009.

Mutterlose, J., Malkoč, M., Schouten, S., Sinninghe Damsté, J. S., and Forster, A.: TEX $_{86}$ and stable $\delta^{18} \mathrm{O}$ paleothermometry of early Cretaceous sediments: Implications for belemnite ecology and paleotemperature proxy application, Earth Planet. Sc. Lett., 298, 286-298, 2010.

Nathorst, A. G.: On the value of fossil floras of the Arctic regions as evidence of geological climates, Geol. Mag. Decade V, 8, $217-$ 225, 1911

O'Connell, S. B.: Sedimentary facies and depositional environment of the Lower Cretaceous East Antarctic Margin: Sites 692 and 692, in: Proc. Ocean Drill. Program, Sci. Results, edited by: Barker, P. F., Kennett, J. P., O'Connell, S., Berkowitz, S., Bryant, W. R., Burkle, L. H., Egeberg, P. K., Fütterer, D. K., Gersonde, R. E., Golovchenko, X., Hamilton, N., Lawver, L., Lazarus, D. B., Lonsdale, M., Mohr, B., Nagao, T., Pereira, C. P. G., Pudsey, C. J., Robert, C. M., Schandl, E., Spiess, V., Stott, L. D., Thomas, E., Thompson, K. F. M., and Wise, S. W., 113, 71-88, Ocean Drilling Program, College Station, Texas, 1990.

Ogg, J. G., Ogg, J., and Gradstein, F. M.: The concise Geologic Time Scale, Cambridge University Press, 177 pp., 2008.

Pearson, P. N., Ditchfield, P. W., Singano, J., Harcourt-Brown, K. G., Nicholas, C. J., Olsson, R. K., Shackleton, N. J., and Hall, M. A.: Warm tropical sea surface temperatures in the Late Cretaceous and Eocene epochs, Nature, 413, 481-487, 2001.

Picard, S., Garcia, J.-P., Lécuyer, C., Sheppard, S. M. F., Cappetta, H., and Emig, C. C.: $\delta^{18} \mathrm{O}$ values of coexisting brachiopods and fish: Temperature differences and estimates of paleo-water depths, Geology, 26, 975-978, 1998.

Pirrie, D., Doyle, P., Marshall, J. D., and Ellis, G.: Cool Cretaceous climates: new data from the Albian of Western Australia, J. Geol. Soc. London, 152, 739-742, 1995.

Price, G. D.: The evidence and implications of polar ice during the Mesozoic, Earth-Sci. Rev., 48, 183-210, 1999.

Price, G. D. and Gröcke, D. R.: Strontium-isotope stratigraphy and oxygen- and carbon-isotope variation during the Middle JurassicEarly Cretaceous of the Falkland Plateau, South Atlantic, Palaeogeogr. Paleocl., 183, 209-222, 2002.

Price, G. D. and Nunn, E. V.: Valanginian isotope variation in glendonites and belemnites from Arctic Svalbard: Transient glacial temperatures during the Cretaceous greenhouse, Geology, 38, 251-254, 2010.

Pucéat, E., Lécuyer, C., Sheppard, S. M. F., Dromart, G., Reboulet, S., and Grandjean, P.: Thermal evolution of Cretaceous Tethyan marine waters inferred from oxygen isotope composition of fish tooth enamels, Paleoceanography, 18, 1029, doi:10.1029/2002PA000823, 2003.

Schlanger, S. O. and Jenkyns, H. C.: Cretaceous oceanic anoxic events: Causes and consequences, Geol. Mijnbouw, 55, 179-
184, 1976.

Schouten, S., Hopmans, E. C., Schefuß, E., and Sinninghe Damsté, J. S.: Distributional variations in marine crenarchaeotal membrane lipids: a new tool for reconstructing ancient sea water temperatures?, Earth Planet. Sc. Lett., 204, 265-274, 2002.

Schouten, S., Hopmans, E. C., Forster, A., van Breugel, Y., Kuypers, M. M. M., and Sinninghe Damsté, J. S.: Extremely high sea-surface temperatures at low latitudes during the middle Cretaceous as revealed by archaeal membrane lipids, Geology, 31, 1069-1072, 2003.

Schouten, S., Hopmans, E. C., and Sinninghe Damsté, J. S.: The effect of maturity and depositional redox conditions on archaeal tetraether lipid palaeothermometry, Org. Geochem., 35, 567571, 2004.

Schouten, S., Forster, A., Panoto, F. E., and Sinninghe Damsté, J. S.: Towards calibration of the $\mathrm{TEX}_{86}$ palaeothermometer for tropical sea surface temperatures in ancient greenhouse worlds, Org. Geochem., 38, 1537-1546, 2007.

Shackleton, N. J. and Kennett, J. P.: Paleotemperature history of the Cenozoic and the initiation of Antarctic glaciation: Oxygen and carbon isotope analyses in DSDP Sites 277, 279, and 281, in Initial Reports of the Deep Sea Drilling Project,edited by: Kennett, J. P., Houtz, R. E., Andrews, P. B., Edwards, A. R., Gostin, V. A., Hajós, M., Hampton, M. A., Jenkins, D. G., Margolis, S. V., Ovenshine, A. T., and Perch-Nielsen, K., 29, 743-755, US Government Printing Office, Washington, 1975.

Sluijs, A., Schouten, S., Pagani, M., Woltering, M., Brinkhuis, H., Sinninghe Damsté, J. S., Dickens, J. R., Huber, M., Reichart, G.-J., Stein, R., Matthiessen, J., Lourens, L. J., Pedentchouk, N., Backman, J., Moran, K., and the Expedition 302 Scientists, Subtropical Arctic Ocean temperatures during the Palaeocene/Eocene thermal maximum, Nature, 441, 610-613, 2006.

Smith, A. G., Hurley, A. M., and Briden, J. C.: Phanerozoic paleocontinental World Maps, Cambridge University Press, 102 pp., 1981.

Stoll, H. M. and Schrag, D. P.: High-resolution stable isotope records from the Upper Cretaceous rocks of Italy and Spain: glacial episodes in a greenhouse planet?, Bull. Geol. Soc. Am., 112, 308-319, 2000.

Tarduno, J. A., Brinkman, D. B., Renne, P. R., Cottrell, R. D., Scher, H. and Castillo, P.: Evidence for extreme climatic warmth from Late Cretaceous Arctic vertebrates, Science, 282, 2241-2243, 1998.

Ufnar, D. F., González, L. A., Ludwigson, G. A., Brenner, R. L., and Witzke, B. J.: Evidence for increased latent heat transport during the Cretaceous (Albian) greenhouse warming, Geology, 32, 1049-1052, 2004.

Urey, H. C., Lowenstam, H. A., Epstein, S., and McKinney, C. R.: Measurement of paleotemperatures and temperatures of the Upper Cretaceous of England, Denmark, and the southeastern United States, Bull. Geol. Soc. Am., 62, 399-416, 1951.

Vandermark, D., Tarduno, J. A., and Brinkman, D. B.: A fossil champsosaur population from the high Arctic: Implications for Late Cretaceous paleotemperatures, Palaeogeogr. Paleocl., 248, 49-59, 2007.

Weijers, J. W. H., Schouten, S., Spaargaren, O. C., and Sinninghe Damsté, J. S.: Occurrence and distribution of tetraether membrane lipids in soils: Implication for the use of the $\mathrm{TEX}_{86}$ proxy 
and the BIT index, Org. Geochem., 37, 1680-1693, 2006.

Weissert, H. and Lini, A.: Ice Age interludes during the time of Cretaceous greenhouse climate?, in Controversies in Modern Geology, edited by: Müller, D. H., McKenzie, J. A. and Weissert, H., 173-191, Academic Press, London, 1991.

Wise, S. W.: Mesozoic and Cenozoic calcareous nannofossils recovered by Deep Sea Drilling Project Leg 71 in the Falkland Plateau region, southwest Atlantic Ocean, in Initial Reports of the Deep Sea Drilling Project, edited by: Ludwig, W. J., Krasheninnikov, V. A., Basov, I. A., Bayer, U., Bloemendal, J., Bornhold, B., Ciesielski, P. F., Goldstein, E. H., Robert, C., Salloway, J., Usher, J. L., von der Dick, H., Weaver, F. M., and Wise, S. W., 71, Part 2, 481-550, US Government Printing Office, Washington, 1983.
Zakharov, Y. D., Shigeta, Y., Popov, A. M., Velivetskaya, T. A., and Afanasyeva, T. B.: Cretaceous climatic oscillations in the Bering area (Alaska and Koryak Upland): Isotopic and palaeontological evidence, Sediment Geol., 235, 122-131, 2011. 